\title{
Roles performed by clinical teachers in undergraduate medical education of Bangladesh.
}

\author{
Shamsuddin AKMI, Humayun Kabir Talukder ${ }^{2}$, Tahmina Nargis ${ }^{3}$, Khairul Alam ${ }^{4}$, Nasrin Sultana
}

\begin{abstract}
A clinical teacher has dual roles to perform in undergraduate medical education along with a major role as patient management. But these roles are not clearly recognized by them. That's why views of clinical teachers and students about roles performed by clinical teachers in undergraduate medical education were studied in eight different government and private medical colleges within and outside Dhaka city. Two sets of questionnaires were developed for teachers and students to explore their views on roles performed by teachers. Total 671 clinical students and 88 clinical teachers having at least two years teaching experience were included. Convenient sampling techniques were used. Seven major roles of clinical teachers were taken into consideration against which teachers and students were expressed their views. Roles were 1. Information provider in the class 2. Role model for the students 3. Students facilitator 4. Curriculum executor. 5. Instructional material creator 6.Student's assessor and 7. Role of teachers on research activities. In this study $52.27 \%$ teachers had experience on workshop and training on teaching methodology and $38.82 \%$ had no experience on teaching and learning. Teachers expressed their views against their performances of all the roles for more than two third classes. While students viewed against teachers performances in less than a half of the classes. Teachers mentioned that excess clinical load, administrative work and bad political environment hampered their teaching roles. They also suggested that different courses on teaching and learning, teacher's evaluation system and regular faculty development programme would help to improve in clinical teaching.
\end{abstract}

Key Words: Clinical teachers, clinical students, roles, undergraduate, medical education.

\section{Introduction}

Clinical teachers have dual roles in medicine, patients care and teach medical students ${ }^{1}$. Though all doctors are well prepared for their clinical roles, few are trained for teaching ${ }^{2}$. A medical graduate become a medical teacher automatically without knowing teaching principles and educational strategies adequately ${ }^{3}$. Though major changes occurred in medical education over the past decades and most of the developed countries moved more towards the recent trends of curriculum little change has been observed in developing countries like Bangladesh. Many role were found important by harden RM \& Crosby J (2000) ${ }^{4}$ for medical teachers to produce good doctors. In this study students and teachers perceptions about the roles performed by clinical teachers in undergraduate medical education were observed.

\section{Methodology}

It was a cross sectional descriptive study done in 8 medical colleges of which four were public and four were private in and outside Dhaka city. Study was carried out from Jan2014Dec $31^{\text {st }} 2014$ with a sample size of 88 clinical teachers and 671 fifth year students. Convenient sampling technique was used with full voluntary participation. Self administered semi

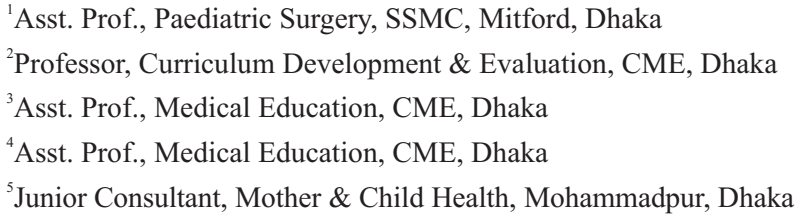

Address of correspondence: Dr. AKM Shasuddin

Asst. Prof., Paediatric Surgery, SSMC, Mitford, Dhaka

E mail: shamsuddin.babu@yahoo.com structured questionnaire were used using English and as well Bengali language for clear perception for students before giving answer. Five point scale using percentages with equal class intervals from $0 \%$ to $100 \%$.. Teachers also asked for identification of the factors that hampers teaching roles and suggestions for good and effective teaching.

\section{Results}

Table 1: Distribution of views of teachers and students as information provider

\begin{tabular}{lcc}
\hline Statements & $\begin{array}{c}\text { students views } \\
\text { Mean }\end{array}$ & $\begin{array}{c}\text { teachers views } \\
\text { Mean }\end{array}$ \\
$\begin{array}{l}\text { Teachers were well } \\
\text { prepared before taking class }\end{array}$ & 63.08 & 83.06 \\
$\begin{array}{l}\text { Teachers informed students } \\
\text { educational objective }\end{array}$ & 37.43 & 72.20 \\
$\begin{array}{l}\text { Teachers competently uses } \\
\text { audio-visual aids in the } \\
\text { class }\end{array}$ & 68.42 & 76.81 \\
$\begin{array}{l}\text { Teachers were concerned } \\
\text { about classroom physical } \\
\text { environment }\end{array}$ & 45.09 & \\
$\begin{array}{l}\text { Teachers provide summary } \\
\text { of the class containing key } \\
\text { points }\end{array}$ & 30.03 & 75.68 \\
$\begin{array}{l}\text { Teachers take care of } \\
\text { individual students for } \\
\text { educational progress }\end{array}$ & 24.78 & \\
\hline
\end{tabular}

Bangladesh Journal of Medical Education 2015;6(1):19-23. (C) 2015 Shamsuddin et al., publisher and licensee Association for Medical Education. This is an Open Access article which permits unrestricted non-commercial use, provided the original work is properly cited. 
Table 2: Distribution of views (mean) of teachers and students as role model for students

\begin{tabular}{|c|c|c|}
\hline \multirow[t]{2}{*}{ Statements } & students views & teachers views \\
\hline & Mean & Mean \\
\hline $\begin{array}{l}\text { Teacher influenced students } \\
\text { for learning by good } \\
\text { personality }\end{array}$ & 53.60 & 49.31 \\
\hline $\begin{array}{l}\text { Teachers gave extra time for } \\
\text { students outside the classes }\end{array}$ & 24.88 & 51.95 \\
\hline $\begin{array}{l}\text { Teachers tried to teach } \\
\text { students by good behavior } \\
\text { and attitude }\end{array}$ & 46.94 & 37.93 \\
\hline $\begin{array}{l}\text { Teachers try to improve } \\
\text { student's moral \& social } \\
\text { values in teaching }\end{array}$ & 50.52 & 79.54 \\
\hline $\begin{array}{l}\text { Students were influenced by } \\
\text { teacher's personality in } \\
\text { career choosing }\end{array}$ & 53.44 & 73.44 \\
\hline $\begin{array}{l}\text { Teachers try to improve } \\
\text { teacher-student relationship } \\
\text { by teaching }\end{array}$ & 30.08 & 76.04 \\
\hline $\begin{array}{l}\text { Teachers always put effort } \\
\text { to eliminate monotony in } \\
\text { the class }\end{array}$ & 33.33 & 75.05 \\
\hline
\end{tabular}

Table 3: Distribution of views (mean) of teachers and students regarding teachers as student's facilitator

\begin{tabular}{lcc}
\hline Statements & $\begin{array}{c}\text { students views } \\
\text { Mean }\end{array}$ & $\begin{array}{c}\text { teachers views } \\
\text { Mean }\end{array}$ \\
$\begin{array}{l}\text { Teachers take special care } \\
\text { to make the class interactive } \\
\text { for learning }\end{array}$ & 24.78 & 71.96 \\
$\begin{array}{l}\text { Help the students to } \\
\text { eliminate examination } \\
\text { related fear. }\end{array}$ & 33.48 & 72.95 \\
$\begin{array}{l}\text { Collect student's personal } \\
\text { information to solve. }\end{array}$ & 45.06 & 54.09 \\
$\begin{array}{l}\text { Take special care for poor } \\
\text { students for their bad } \\
\text { performances } \\
\begin{array}{l}\text { Finding students weakness } \\
\text { teachers gave feedback }\end{array}\end{array}$ & 30.73 & \\
$\begin{array}{l}\text { Teachers act as a personal } \\
\text { coach to improve } \\
\text { clinical/practical skills }\end{array}$ & 40.93 & 66.84 \\
\hline
\end{tabular}

Table 4: Distribution of views (mean) of teachers and students regarding teachers as curriculum executor

\begin{tabular}{lcc}
\hline Statements & $\begin{array}{c}\text { students views } \\
\text { Mean }\end{array}$ & $\begin{array}{c}\text { teachers views } \\
\text { Mean }\end{array}$ \\
$\begin{array}{l}\text { Teachers always taught us } \\
\text { from the curriculum }\end{array}$ & 60.55 & 71.59 \\
$\begin{array}{l}\text { Teacher's tries to co- } \\
\text { ordinate between different } \\
\text { subjects of curriculum. }\end{array}$ & 77.64 & 59.31 \\
$\begin{array}{l}\text { Teachers take part in } \\
\text { extracurricular activities. }\end{array}$ & 34.78 & 77.95 \\
\hline
\end{tabular}

Table 5: Distribution of views (mean) of teachers and students regarding teachers as student's assessor

\begin{tabular}{lcc}
\hline Statements & $\begin{array}{c}\text { students views } \\
\text { Mean }\end{array}$ & $\begin{array}{c}\text { teachers views } \\
\text { Mean }\end{array}$ \\
$\begin{array}{l}\text { Teachers prepare questions } \\
\text { for examination by } \\
\text { themselves }\end{array}$ & 64.11 & 71.88 \\
$\begin{array}{l}\text { Teachers prepare all } \\
\text { questionnaires from the } \\
\text { curriculum. }\end{array}$ & 59.16 & 74.54 \\
$\begin{array}{l}\text { Teachers showed no } \\
\text { partiality in the assessment }\end{array}$ & 57.98 & 67.72 \\
\hline
\end{tabular}

Table 6: Distribution of views (mean) of teachers and students regarding teachers as instructional materials creator

\begin{tabular}{lcc}
\hline Statements & $\begin{array}{c}\text { students views } \\
\text { Mean }\end{array}$ & $\begin{array}{c}\text { teachers views } \\
\text { Mean }\end{array}$ \\
$\begin{array}{l}\text { Teachers prepare } \\
\text { instructional materials for } \\
\text { teaching }\end{array}$ & 64.82 & 86.45 \\
$\begin{array}{l}\text { Teacher prepare and collect } \\
\text { resource material for the } \\
\text { students for their learning } \\
\text { (case, models, pictures \& } \\
\text { simulations etc) }\end{array}$ & 39.86 & 75.56 \\
\hline
\end{tabular}

Bangladesh Journal of Medical Education 2015;6(1):19-23. 
Table 7: Views (mean) of teachers regarding factors hampering teaching roles

\begin{tabular}{lc}
\hline Statements & teachers views \\
& Mean \\
Involved in personal research activities & 58.21 \\
Publishing research work regularly & 60.56 \\
Participate in national/international & 47.50 \\
research work & 67.15 \\
Participate in all CME activities. & \\
\hline
\end{tabular}

Table 8: Views (mean) of teachers regarding factors hampering teaching roles

\begin{tabular}{lc}
\hline Statements & teachers views \\
& Mean \\
Personal private practice & 20.45 \\
Personal illness & 47.04 \\
Political environment & 46.81 \\
Caring family members & 27.47 \\
Institutional administrative activities & 46.02 \\
Excess clinical load & 50.90 \\
\hline
\end{tabular}

Table 9: Suggestions to improve clinical teaching, teacher's views

\begin{tabular}{|c|c|}
\hline \multirow[t]{2}{*}{ Statements } & teachers views $(\%)$ \\
\hline & Mean \\
\hline $\begin{array}{l}\text { Regular workshop on teaching and } \\
\text { learning }\end{array}$ & 83.9 \\
\hline Training on teaching and learning & 60.9 \\
\hline $\begin{array}{l}\text { Educational course on teaching } \\
\text { methodology: }\end{array}$ & 91.9 \\
\hline Non-practice allowance & 46.00 \\
\hline $\begin{array}{l}\text { Promotion based on teaching } \\
\text { experience }\end{array}$ & 63.20 \\
\hline Special award for good teaching & 73.60 \\
\hline Exercising teacher evaluation system & 77.00 \\
\hline $\begin{array}{l}\text { Implementing faculty development } \\
\text { program }\end{array}$ & 56.00 \\
\hline
\end{tabular}

\section{Discussion}

Information provider: In this study regarding the item 'teachers were well prepared' teachers and students mean views were 83.06 and 63.08 respectively, supporting to the majority. Miah MAS (2013) in study found that students highly expected for their teacher to be well prepared for class $^{5}$. Mean views of teachers and students for setting educational objectives in the class were 72.20 and 37.43 which showed a dissimilarity this is due to either teachers were not mentioned educational objectives regularly or students failed to understand which is ultimately teachers failure. Rahman MM (2014) in his study observed that $53.3 \%$ teachers failed to mention educational objectives clearly ${ }^{6}$ which is closer to the students views of this study. It was found that $81.4 \%$ teachers mentioned that they use audio-visual aids competently, $72.9 \%$ students also supported teachers statement. Rahman MM (2014) in his study also found that $78 \%$ teachers use audio-visual aids competently which similar to the finding of this study ${ }^{6}$. Among the teachers $75.68 \%$ mentioned that they have taken care of physical environment of the class. Against this item only $45.09 \%$ students made similar statement. Similar observation also made by Rahman MM (2014) where $59.2 \%$ students agreed that teachers were concerned about physical environment of the class ${ }^{6}$. At the end of the class $75.11 \%$ teachers mentioned they provide summary but students expressed differently and they viewed that only in $30.03 \%$ classes summary was given. This great discrepancy might be due to students were not attentive at the end of the class or teacher were not provided any summary. Similar observation was made by Sarker \& Majumder (2013) and they found that $65.3 \%$ classes summarization was not done which supported students views?. In another study Mohammed (2008) observed that on 50\% classes summarization was not done ${ }^{8}$. In this study it was found that majority $(66.59 \%)$ teachers mentioned they actively guided students for to acquire clinical and practical knowledge whether only $24.78 \%$ students were supporting this item with same view. Majority students were disagreed with teachers views.

Role model: In this role $53.61 \%$ teachers mentioned that they influenced students by their personality, $49.31 \%$ students also expressed similar views. About half of the teachers $(51.95 \%)$ mentioned that they gave extra time outside the class to solve student's queries. Whereas only a fourth $(24.88 \%)$ students mentioned that teacher gave them extra time to help learning. This extra time was not needed for all student, some students willingly took help and majority didn't seek help due to fear and shyness that's why great differences existed in this item between teachers and students views. Nargis T (2013) in her study observed that $40.01 \%$ students agreed that teacher gave extra time to counsel and advice students outside the class ${ }^{9}$. It was viewed that $47.93 \%$ teachers taught students with good behavior and attitude on the other hand $46.93 \%$ students also made similar statement. Among the teachers $79.54 \%$ mentioned that they tried to improve social \& morale values to the students. But $50.52 \%$ students on the statement made by teachers. For students future career choosing $79.54 \%$ teachers influenced them showing enthusiasm on own specialty and $53.44 \%$ students also supported this view. In this study $76.04 \%$ students mentioned that they tried to

Bangladesh Journal of Medical Education 2015;6(1):19-23. 
develop and maintain teacher student's relationship whereas only $30.08 \%$ students viewed in favor of teacher's opinion. In the last item majority ( $75.05 \%$ ) teachers mentioned they always put some efforts to eliminate monotony of the class but very few students $(33.33 \%)$ showed similar agreements. Instead of majority teachers effort classes are not interesting to the students, teachers had to work hard in this area as interesting classes bring good learning.

Student's facilitator: Among the teachers majority $(71.96 \%)$ stated that they have taken special care to make class interactive but only a fourth (24.78\%) students supported this view. According to majority students classes were not interesting so the efforts of the teachers to make classes interesting were inadequate or ineffective. Mia MAS (2013) ${ }^{5}$ in his study found $55.5 \%$ students were highly expected from the teachers to make classes interesting to them. It was found that majority $(72.95 \%)$ teachers mentioned that they tried to eliminate examination related fear, confusion and stress but only a third (33.48\%) students were in favor of teachers views. This discrepancy between these views may be due very few teachers bother for this examination related stress rather they consider it as a normal phenomenon. But mere counseling may reduce this fear and stress which will improve ultimate outcome in the result. Nargis T (2013) ${ }^{9}$ in a study observed that students viewed that their teachers did not provide them adequate support and guidance for examination. A half of the teachers (54.09)\% teachers mentioned that they collected student's personal academic information regarding their bad progress and tried to solve that but half of the (54.06\%) students also supported this view and the rest didn't. Half of the teachers and students both were agreed that teachers didn't collect students academic records to find the way of progress either may be due to teachers remained busy had less time to collect records or they didn't find it as an important task. It was also found that more than two third teachers $(86.84) \%$ mentioned that they have taken special care for poor performing students on the contrary only less than a third of the students $(30.73) \%$ agreed for this view and majority didn't as they considered their teachers efforts for this item insufficient. Rahman MM (1024) ${ }^{6}$ in a study in different medical colleges of Bangladesh found that $53.4 \%$ students viewed that their teachers fails to take necessary action for the poor performers in the class. It was revealed in this study that after finding weakness majority (69.77\%) teachers provided feed back to the students but only less than a half $(40.93 \%)$ students supported this opinion majority were disagreed. This may be due to either feedback was not given adequately or student viewed this insufficient. Mia MAS (2013) ${ }^{5}$ observed that majority medical students were highly expected of getting adequate feedback from the teachers to improve their learning. To improve clinical and practical skills most of the teachers $(78.18 \%)$ mentioned that they acted like personal coach where as only less than a half $(42.72 \%)$ students stated similar opinion. Clinical teachers were loaded with clinical works and it was difficult for them to act as a personal coach which is time consuming. But in a small group teaching they can perform this role with good outcome.
Curriculum executor: In this study most of the teachers (71.59\%) mentioned that they always taught students within the curriculum and majority students also supported this view. In this study $59.31 \%$ teachers and $47.64 \%$ students opined that teachers were tried to coordinate between different subjects of curriculum. Among the teachers $77.95 \%$ mentioned that they took part in different extracurricular activities but only $34.78 \%$ students showed similar perceptions.

Student's assessor: most of the teachers (77.88\%) mentioned that they prepared questions for students by themselves which was supported by majority students $(64.11 \%)$ views. Majority teachers $(74.54) \%$ and students $(59.16) \%$ opined that teachers prepared questions for the assessments within the curriculum. Majority teachers (67.72)\% and students (57.98)\% agreed that teachers remain impartial during assessments but one third teachers and students viewed that teachers were not neutral during judgment for students in the examination. There might be some external factors that made teachers not to be impartial to the students as they boldly viewed their shortness in this point.

Instructional material creator: It was found that Majority teachers $(86.45) \%$ and students $(64.82) \%$ opined that teachers prepared instructional materials for the students for their learning. Majority teachers $(75.56 \%)$ mentioned that they prepared or collect institutional resource materials for learning but only $39.86 \%$ students mentioned similar statements and majority didn't. To improve clinical and practical knowledge various instructional materials needed to collect by teachers. A good clinical teacher always had a search for good instructional materials like good simulators, cases, $\mathrm{x}$-rays, specimens, photographs and models. Though this is time consuming but this is very much effective in integrated learning and long term retention of clinical knowledge by the students. Mia MAS $(2013)^{5}$ found that $90 \%$ students were highly expected for useful instructional materials for them from the teachers.

Research role: In this study majority (58.21\%) teachers mentioned they participate medical research activities and developments and majority $(60.56 \%)$ also mentioned that they published research works regularly. In the national or international research works $47.55 \%$ teachers mentioned that they took part actively. They also (67.15)\% mentioned that they participate all CME activities like seminar, workshop and conference etc.

Factors hampering teaching roles: Clinical teachers have duel roles as they remain busy with patient management in the clinical wards and simultaneously involved with teaching both in the clinical settings like wards, outdoor and operation theater as well as in the lecture classes. So there seemed many factors hampering teachers teaching performances. According to the views of the teachers, personal private practice, caring of family members and personal illness hampered teaching roles to some extent. Where as bad political environment and administrative works and excess clinical load hampered teaching mostly.

Bangladesh Journal of Medical Education 2015;6(1):19-23. 
Suggestions to improve teaching performances in medical education: On the basis of teachers views majority suggested for regular workshop and local or foreign training on teaching and learning. Most of the teachers also suggested for different educational courses. Other suggestions are non-practice allowance, promotion based on teaching experiences, special award for good teaching. Majority teachers also suggested for exercising teacher evaluation system and implementing faculty development programme respectively.

\section{Conclusion}

Teaching is one of the major role of a clinical teacher of undergraduate medical education is often inadequately prioritized. There are more roles that teachers have to perform along with patient management for better students learning in attaining skills of medical profession. All these roles they had to perform were not equally emphasized. It was found that for most of the items of this teaching roles teacher's performance was poor. Though teacher's performance on some roles like information provider and assessor was high but in many other roles their performances was found very poor. Factors like excess clinical load and administrative activities and political environment were considered as responsible for hampering clinical teaching roles. Regular workshop, training, different course on teaching learning, teacher evaluation system, promotion based on teaching experience and implementing faculty development programme were suggested by the teachers to improve their teaching performances.

\section{References}

1. Ludmerer K 1999. Time to heal. New York, NY. Oxford university press.

2. Steinert Y, Cruess R, Cruess S, Boundreau JD, Fucs A 2007. Faculty development as an instrument of change; A case study of teaching professionalism, Acad med. 2007; 82; 1057-1064.
3. Wilkerson L, Irby DM. 1998. Strategies for improving teaching practices: a comprehensive approach to faculty development. Acad Med 73:387396.

4. Harden RM, Crosby J. 2000. AMEE Guide No 20: The good teacher is more than a lecturer: the twelve roles of the teacher. Med Teach 22:334347.

5. Mia MAS 2013. Expectations of students from their teachers in undergraduate medical education in selected medical colleges of Bangladesh. Thesis for masters in medical education. Bangladesh Sheikh Mujib Medical education

6. Rahman MM 2014. Assessing the role of medical teacher in managing teaching learning situation in the lecture class of selected medical colleges. Thesis for masters in medical education. Bangladesh Sheikh Mujib Medical University

7. Sarker AP, Majumder G 2013. Perception of lecture in Community Medicine among students of West Bengol in India. Reviews of progress, 1(17), 1-7.

8. Mohammad S2008. A situation analysis of current large group teaching in medical colleges of Dhaka city. Thesis for masters in medical education. Bangladesh Sheikh Mujib Medical University

9. Nargis T 2014. Hidden curriculum in undergraduate medical education of Bangladesh: Medical student' perceptions. Thesis for masters in medical education. Bangladesh Sheikh Mujib Medical University

Bangladesh Journal of Medical Education 2015;6(1):19-23. 